\title{
Environmental hazard and water quality: the River Platani basin
}

\author{
V. Liguori \& G. Manno \\ Dipartimento di Ingegneria Strutturale e geotecnica, \\ Facoltà di Ingegneria, Università degli Studi di Palermo, Sicilia, Italy
}

\begin{abstract}
The River Platani, situated in the western side of Sicily, is one of the greatest rivers of the island. It runs for about $103 \mathrm{Km}$ and the basin extends to about 1,784.9 $\mathrm{Km}^{2}$. It rises near Santo Stefano Quisquina (Ag); the river flows to Capo Bianco (Ag) ends in the Mediterranean Sea. The morphology of the basin is predominantly characterized by rises of modest entities with slopes sweet or calanques. In the containing gypsum and carbonatic stony heaps are diffused the karst phenomena. In the Platani basin some mines are located of rock salt and potassium salts; today the mines are closed after a long activity and they interact with the geomorphology of the territory and on the water quality of the river. An example is given by the ex mine "Muti-Coffari" (Ag), in fact the mine determines an evident incidence on the physical-chemical characteristics of the water and the fluvial ecosystem. Where the "sinkholes" are present, caused by the incessant thinning of the vault and pillars of the mine's tunnel, meteoric water penetrates inside, flooding all the underground levels; the waters, through different chemical process, attach the evaporitics rocks and they have a concentration of salts. Consequently, because of the flooding of the tunnels, the saturated salt waters escape from the entrance of the mines to flow into the River Plantain. Through the monitoring of the principal branch of the River Platani it can be deduced that the river can be considered constituted by two separate ecosysystems: the first goes from the source to the point of immission of the small affluent coming from the mine; the second extended from the salt mine up to the mouth. Observing the graphs products on the chemical-physical parameters evident as the element of separation is constituted by the immission of saturated salt water. After the immission of the Torrente Salina, the values of the sulphates, of the chlorides, and of the sodium, sensitively increase. The environmental aspect that derives is a hyper saltiness that affects the fluvial ecosystem, as a matter of fact a desertification of fertile areas where once there were very fertile cultivations.
\end{abstract}

Keywords: river basin, ecology, environmental risk, water quality. 


\section{Introduction}

The watershed of the Platani River is situated in the western centre of Sicily, fig. 1, and has a total surface of $1.784,9 \mathrm{Km}^{2}$. It extends along in a NE-SW direction (in the map of Sicily). It includes 46 communes pertaining to territory limits to the provinces of Agrigento, Caltanissetta and Palermo, see fig. 2.

The River Platani starts around the premises of S. Stefano Quisquina (province of Agrigento) around Pizzo Confessionario. It flows for $103 \mathrm{Km}$, ending into the Mediterranean sea near Capo Bianco with a front of about $4 \mathrm{Km}$.

The basin starts from the Sicani mountains, which is the highest peak located in the north-western sector between the provincial territories of Palermo and Agrigento (Serra della Moneta, 1,188 m o.s.l.; Serra Quisquina, m 1,169 m o.s.l..; Pizzo Stagnataro, 1,346 $\mathrm{m}$ o.s.l.) and in the north-eastern sector near Valledolmo (Pizzo San Pietro, 1,018 m o.s.l., Serra di Puccia, m 1,052 o.s.l.; Monte Catuso, m 1,042 o.s.l.).

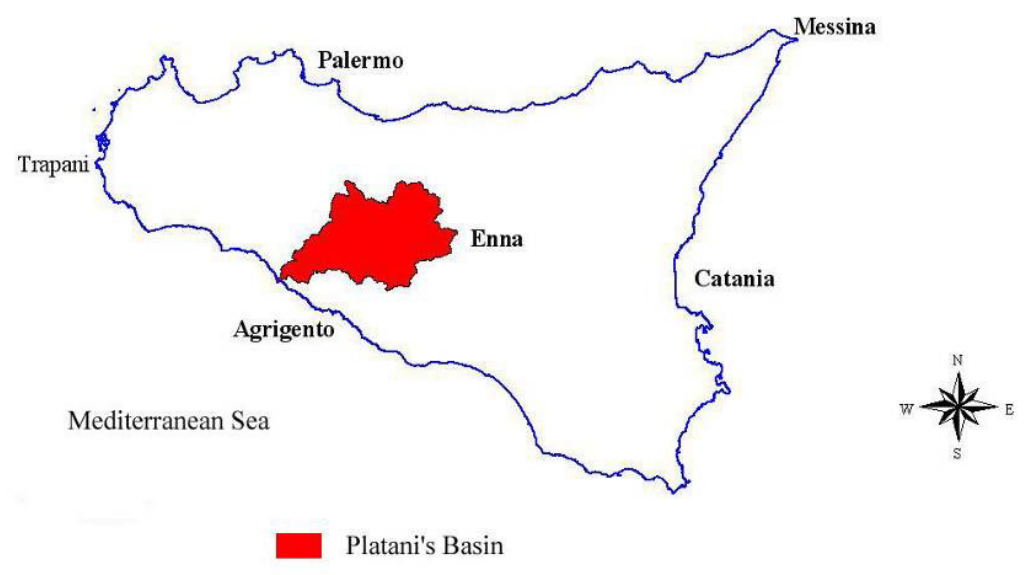

Figure 1: Location of the Platani basin in Sicily.

The highest parts of the mountains are located in the north-western side of the basin: the mountain range of Monte Gemini (1,392.4 m o.s.l.) and Monte Cammarata (1,578 m o.s.1.).

The basin flows beside a road called Strada Statale 189 and the railway track Palermo-Agrigento. It flows to the territory of Castronovo di Sicilia (province of Palermo), where the lake has created a dam called "Diga Fanaco" $\left(24.4 \cdot 10^{6} \mathrm{~m}^{3}\right)$, a barrage of the Platani River.

The lake supplies water to the various communes of the province of Agrigento. 


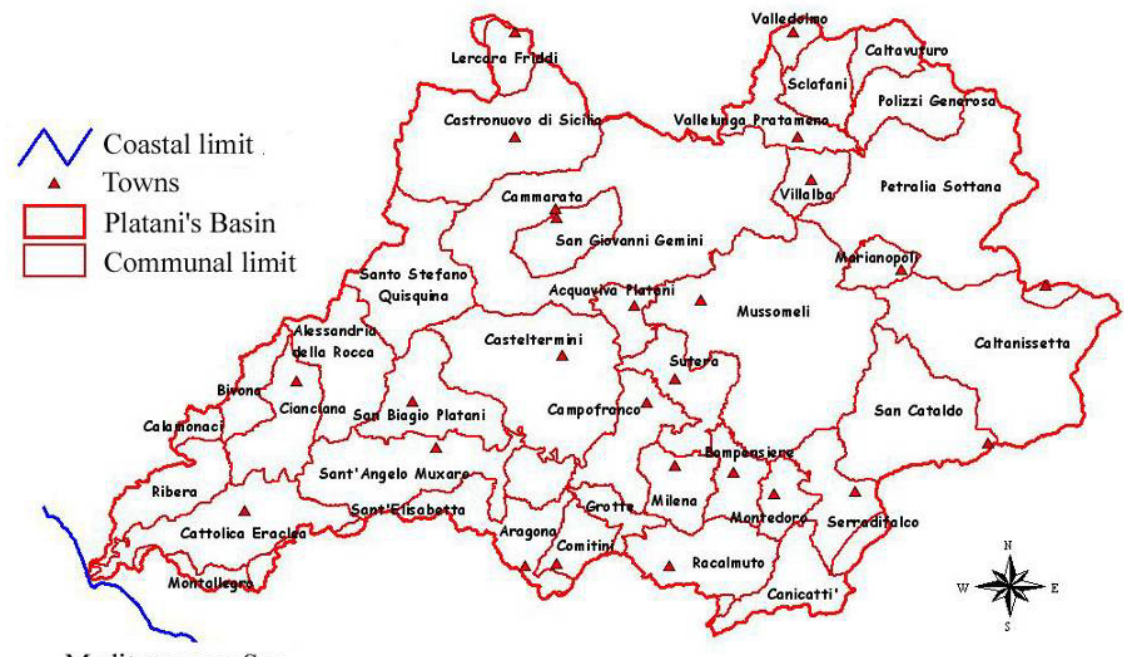

Figure 2: Boundary limits.

\section{Geological and geomorphological aspects}

The basin of the Platani River, on the geological side, is characterized by two sectors:

1 North-western side the lithological terms belong to Catena AppenninoMaghrebide forming the Monti Sicani.

2 Southern side formed mostly of post orogenetic lithology prevalently belonging to the "Formazione Gessoso Solfifera" upper Miocene and mostly argillaceous sandy calcarenitical terms plio-quaternary.

The Monti Sicani are the southern sector of the western segment of the "Catena Appenninico Maghrebide"; it rises as a deformation of "Dominio Sicano" formed by Mesozoic carbonatic rocky units and by "Flysh Numidico".

The "Catena Appennino Maghrebide" is the product of the mio-pliocenic deformation of different carbonate platforms and pelagic basins, deposit are piled up with ramp-flat and duplex style and located during the mosozoic-tertiary along the northern African continental margin, Renda and Nigro [1].

In the southern area of the basin appears the lithology belonging to the "Formazione Gessoso Solfifera", the lithological succession is: diatomites, evaporitical limestones, gypsums, salts with clay intercalations, marls and limestones. This formation rests in discordance on pre-evaporitic deposits "Formazione Terravecchia" (Upper Tortonian - Lower Messinian) and it is covered in discordance, with calcilutite constituent "Trubi" (Lower Pliocene) Catalano and Argenio [2].

The evaporitic rocks settled during the Messinian in coincidence with the paleogeographic event of the closing of the Mediterranean basin. This event 
happened after the continental collision between Spain and Africa as a coincidence the closing of the straits of Gibraltar. The closing of the Mediterranean sea caused an hidrological deficit, lowered the sea level, wide areas surfaced and the creation in the deeper areas of basins where the evaporates were deposited, Agnesi et al [3].

The water of the Platani River, originated from Monte Cammarata crossing the southern side of the basin, is constituted mostly of evaporitic rocks, (rich in gypsum and halite). So the water became particularly brackish like the nearby "Imera meridionale" River.

The average altitude level of the basin is $439 \mathrm{~m}$ o.s.l. The morphology of the basin changes, moving from the northern side of the start, depending on the lithologies that characterized the landscape.

The general aspect of the northern side is mountainous with carbonatic relief more or less sheer, with slope incised with ripid valley lines that flow together in the principal stream. In the central side of the basin the landscape becomes hilly and this influences the different characteristics of erosion of the lithologies in outcrop: the harder morphologies on the rocky cluster, while the slightest morphology are bound with terms of argillaceous and marly.

Proceeding along the SW direction to the start of the basin zone, the predominant element morphological is caused by an alluvional valley floor. Here the rivers have a course, mostly like a meander, up until it reaches the sea near to NW called Capo Bianco.

Relative to the use of the soil, inside the river basin there are vineyards, citrus groves, olive groves, simple irrigous and arboreus seminative, gardens, annual cultures and permanent cultures.

The landscape is also mainly covered with broadleaf trees, conifers, mixed forest maquis, areas with shrubby woody vegetation and with uncultivated zones. The use of the soil is $77 \%$ seminative and $13 \%$ with tree cultures.

The course of the precipitation in the river basin is various, according to the change of altitude. Proceeding through the mountain area of Cammarata, Santo Stefano Quisquina, Castronovo di Sicilia, and up to the cliff the temperatures increase while the precipitations diminish, giving rise to frequent and long periods of dry weather.

\section{Mines}

The Sicilian southern subsoil, formed by evaporated rocks, have, over the years, become areas of interest in the past for its numerous mines used mostly for the extraction of sulphur, and in recent times for the extraction of potassic and sodic salts. Most of the salt mines are located in the province of Enna, Caltanissetta and Agrigento.

The evaporated rocks have generated large deposits for the Formazione Gessoso Solfifera mostly found in the watershed of the Platani River; they are still nowadays the object of interest for the mining extraction.

Table 1 shows the mines and the caves belongings to each territory at different Communes. 
Table 1: $\quad$ List of anthropic activities.

\begin{tabular}{|l|c|c|c|}
\hline \multicolumn{1}{|c|}{ Commune } & Caves & Mines & Solfatara \\
\hline Aragona & & 1 & \\
\hline Caltanissetta & 1 & & 4 \\
\hline Casteltermini & & 3 & \\
\hline Cattolica Eraclea & 1 & & \\
\hline Cianciana & & 5 & \\
\hline Comitini & & 1 & 3 \\
\hline Milena & & & 1 \\
\hline San Biagio Platani & 1 & & \\
\hline San Cataldo & & 1 & 1 \\
\hline
\end{tabular}

The territory, therefore, has suffered and still suffers for the modifications caused by the various geomorphologic conditions generated for the exploration of mining on the surface and underground, evidenced by looking at the already exhausted cultivations. In the territories where there were mining activities a deep and heavy dynamic mechanisms has developed that sometimes is observed on the surface showing the unforeseeable and uncontrollable phenomena that man can control.

This phenomena, the most common called subsidence, is more evident in areas where extractive activities have been carried out, especially mineral salts. This event caused the formation of great "sinkholes" and landslides in tandem with the underground workings, with enormous damage to the surface.

The salt has a mechanical behavior that is commonly defined as not linear, and depends on its chemical composition, " granulmetrics of crystals", are particularly visco-elastic and have a plastic behavior and are sensitive to the underground microclimate. The subsidence for the presence of the cavities can be emphasized for the presence of seismic, alluvional phenomena, and the erosion of the versant.

Other negative effects on the environment linked to the mining activities, are:

1. mobilization of the melted refusal materials that accumulate in the dump in some parts of the versant with an incline variable;

2. the alteration of the superficial and underground hidrology and the harvest in the dug areas of meteoric water consequently has an emission with brackish waters or for interception of water stratus;

3. the supercharging of the hydrographical net with fine and rough detritus that can cause pollution;

4. modifications of the morphology and the destruction of the vegetation with modification of the landscape.

It is the second effect that causes the changes to the Platani River, an effect caused by the brackish waters that come out from the Mine "Muti-Coffari", with the consequent risk to the environment and which modifies the surrounding territory and water risk for the fluvial ecosystem of the Platani River. The salt mine is an example that constitutes the risk for the natural environment, linked to the already existing anthropic cavities (abandoned mines). The mine "MutiCoffari", is located in "Contrada Salina", in the territory of Cammarata, in the 
province of Agrigento where the lithologies in outcrop are gypsum and clay, Liguori et al [4]. Now the mine has been stopped because of exhaustion. In the winter of 1994 the mine suffered a sinkhole that has produced a sinking of the plan of 30 meters involving the first two galleries of the mine, fig. 3 . The river of mud, water and salt coming out from the mine, fortunately did not sweep up the nearby bridge of the Strada Statale n.189 but channeled itself below the river bed. However, the waters eroded the land for a depth of 1.5 meter, also affecting the supporting structure of the subway of the Strada Statale 189.

The overlooking zones were the mines were located has started a trigger of complex landslides (rock slumps followed from mud flow) whose evolution has created numerous surface depressions, very visible on the north side of the Vallone Salina.

Moreover this phenomena can be considered the cause of the chemical alteration of the hydrological characteristics of the Platani's River. In fact the water of the Vallone Salina enters from a natural well and falls in the mine, dissolving the salts. The water that is not infiltrated in the subsoil comes out from the entrance of the mine and flows in the Platani River rendering its water salty and polluted. The presence of the mine determines an obvious record on the state of water since it pours, above all in winter, and the salt continues to pollute the Platani. The halite that flows in the river, drying up the soil, causes the death of fish, alters the ecosystem and generates desertification of the fertile areas. The most involved areas from the effects caused by the hypersalinity of the river are those of Acquaviva Platani. Here waters (of the Platani) cannot be used for the irrigation of citrus groves and orchards placed along the sides of the river, Campofranco and Sutera.

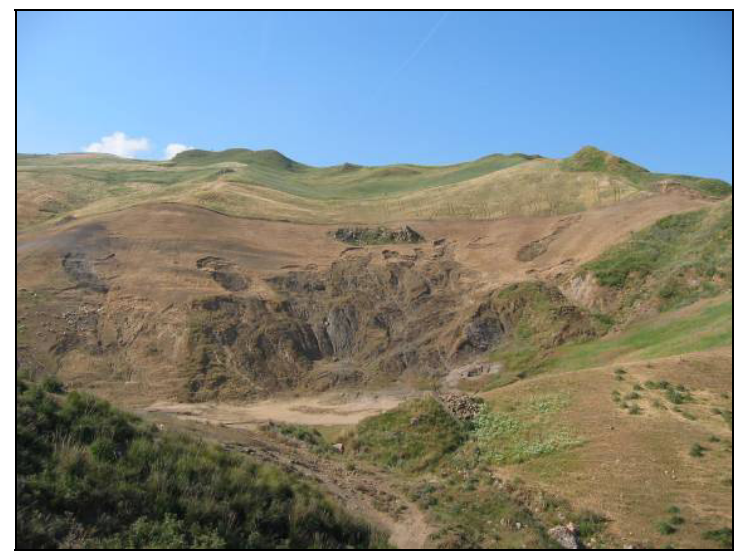

Figure 3: $\quad$ Sinkhole of winter 1994. 


\section{Qualitative monitoring of River Platani}

In the month of December 2001 the monitoring of the area was organized to ascertain the qualitative state of the waters of River Platani, Mortellaro [5].

Along the principal course of the river, from the start up to the lake Fanaco, with 13 stations of sampling to test the water, the sampling, as shown in table 2 in which both the analysis in the field (measure of the dissolved $\mathrm{O}_{2}$, temperature of the air and the water) and chemical analysis of the waters that have been checked in a laboratory, have been carried out.

The location of the stations has been selected on the basis of the peculiarities found in the river, in relation to particular situations of antropic impact which clearly have influenced the quality of the waters: presence of inhabited centers, presence of urban and industrial emissions, immission of principals tributaries.

Table 2: $\quad$ Sampling station.

\begin{tabular}{|c|c|c|c|}
\hline ID & Sampling Station & ID & Sampling Station \\
\hline 1 & $\begin{array}{l}\text { Landslide on the Platani } \\
\text { (c.da S.Andrea) }\end{array}$ & 8 & Acquaviva Platani station \\
\hline 2 & Bridge Vecchio: Castronovo & 9 & Fonnuto Pass: SS189 \\
\hline 3 & $\begin{array}{l}\text { After the valley of the } \\
\text { freshet Morello }\end{array}$ & 10 & $\begin{array}{l}\text { Bridge S.Biagio Platani - } \\
\text { S.Angelo Muxaro }\end{array}$ \\
\hline 4 & $\begin{array}{c}\text { Cammarata - } \\
\text { Village Regalmici Road }\end{array}$ & 11 & Bridge Raffadali-Cianciana \\
\hline 5 & Crossroads Tumarrano & 12 & $\begin{array}{c}\text { Bridge Cattolica Eraclea- } \\
\text { Cianciana }\end{array}$ \\
\hline 6 & $\begin{array}{c}1 \mathrm{~km} \text { downstream of the Mancuso } \\
\text { Bridge: SS189 }\end{array}$ & 13 & Mouth of the River Platani \\
\hline 7 & After the valley of the mine salt & & \\
\hline
\end{tabular}

In some cases the locations of the selected sites to test the waters have been changed because they were very difficult to reach, but only after being sure that the distance of the points of sampling from the above-mentioned immissions was enough to guarantee the full remixing of the waters, with the purpose to estimate the quality of the water receptor and not that of the emissions.

Station $n^{\circ} 1$ was located near the "Contrada S.Andrea" where the River Platani sets again its natural course, after having been canalized for 150 meter in an artificial canal. The canal takes the waters from the artificial lake that was created following the landslide, to the lake Fanaco.

Station $n^{\circ} 2$ has been selected in "Ponte Vecchio". This is the first bridge built on the River Platani (1951) and it is disfigured by the presence of a modern bridge. It is evident that the presence of the foam was probably due to the dumping of the commune of Castronovo of Sicily and Lercara.

Station $n^{\circ} 3$ has been situated after the flow in the valley of the "Vallone Morello".

Station $n^{\circ} 4$ has been situated near by the bridge on the road that branches from the Strada Statale 189 to the road that goes to "Borgo Regalmici". 


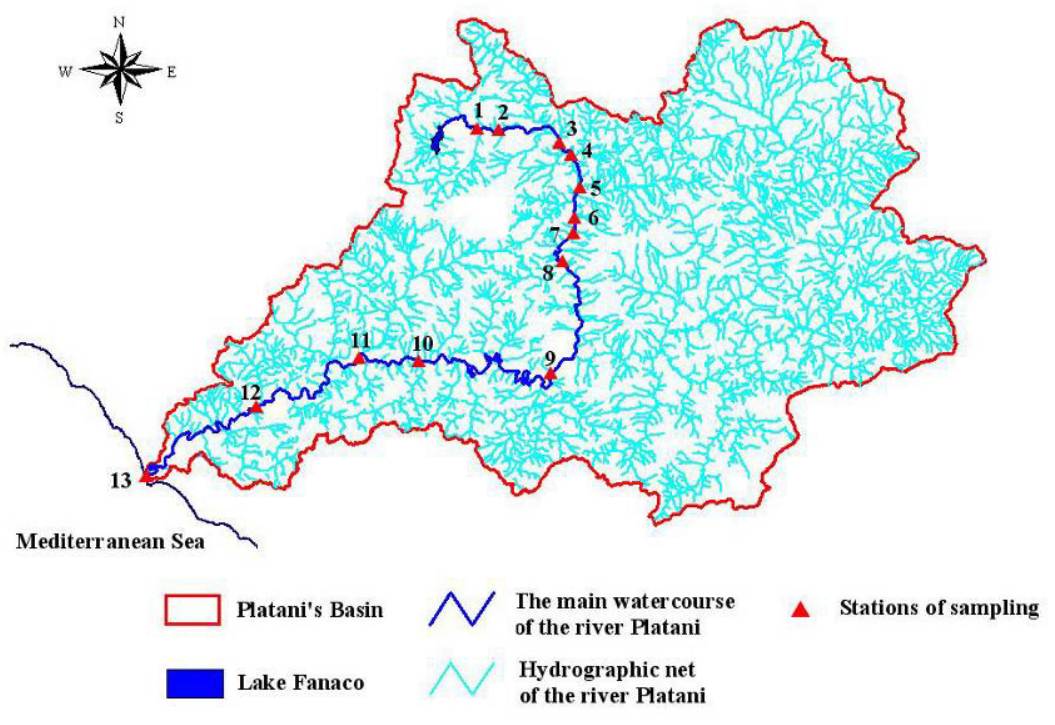

Figure 4: Sampling station.

Station $n^{\circ} 5$ has been selected near by the bridge on the flood called the "Torrente Tumarrano". Station $\mathrm{n}^{\circ} 6$ has been situated in a location $1 \mathrm{~km}$ downstream of the Ponte Mancuso, since the stream under the bridge was hardly attainable for the presence of enclosure and high vegetation. Besides, the stream was polluted by the wastewater coming from Cammarata. The sample has been taken after having guaranteed a dilution of the waters.

Station $n^{\circ} 7$ has been situated in the location of the ex salt mine, called "Muti - Coffari". The presence of the salt along the edges and on the bed of the "Vallone Salina" coming from the mine flows on the right bank of the River Platani.

Station $n^{\circ} 8$ has been situated near the Acquaviva Platani station, after it has gone under the viaduct that goes to the Strada Statale 189.

Station $n^{\circ} 9$ is selected near to the "Passo Fonnuto".

Station $\mathrm{n}^{\circ} 10$ has been situated near to the bridge that connects S. Biagio Platani with S. Angelo Muxaro.

Station $n^{\circ} 11$ has been situated near to bridge of the Strada Statale 118 that connects Cianciana with Raffadali. Along the bed of the Platani River there are brushwoods and some part of pebbles and gravel.

Station $\mathrm{n}^{\circ} 12$ has been situated near to the bridge to the road that connects Cattolica Eraclea with Cianciana. The presence of foam has been revealed, due probably to the dumping of water from the commune of Cattolica Eraclea.

Station $\mathrm{n}^{\circ} 13$ has been situated near to the mouth of the Platani River where there is the headquarters of a Reserve called "Riserva Naturale Orientata", situated in a territory called "Capo Bianco". 

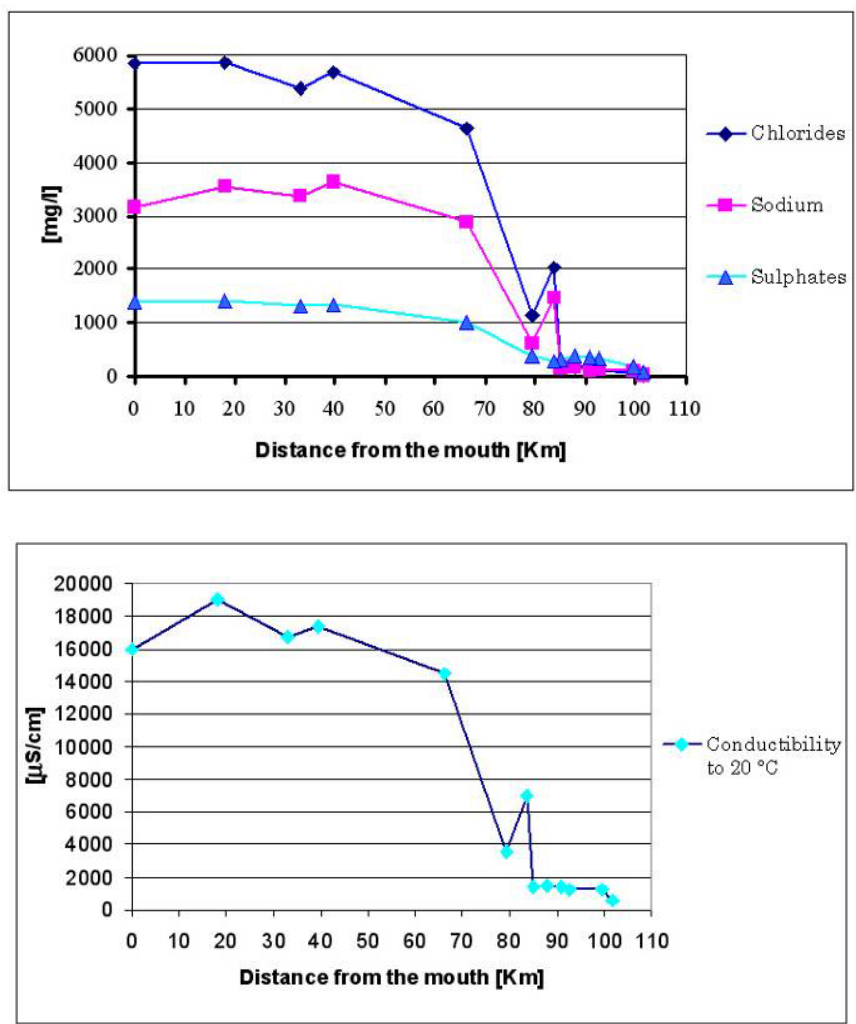

Figure 5: State of salts, sulfates and conducibility along the main course.

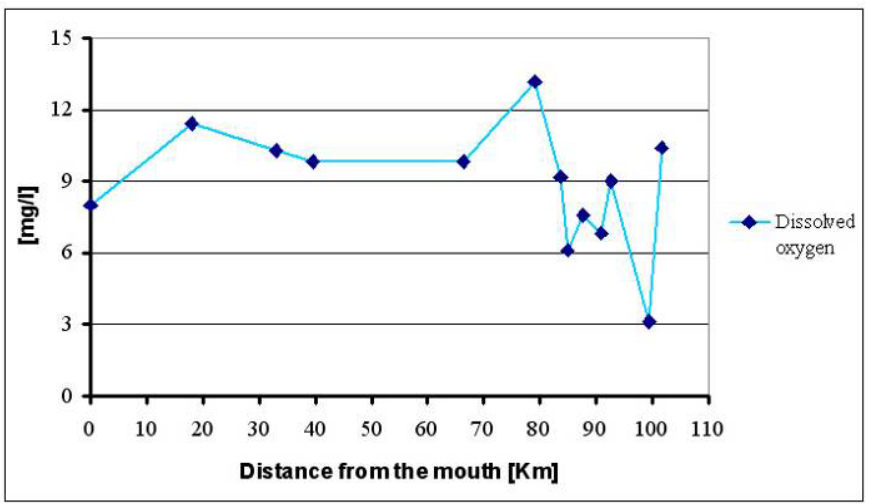

Figure 6: $\quad$ State of the dissolved oxygen along the main course.

During the experiment the following parameters have been monitored: external temperature, temperature of the water, dissolved oxygen, BOD, COD, TOC, N, P, conductibility, surface-actives, $\mathrm{Cl}^{-}, \mathrm{SO}_{4}^{--}, \mathrm{Na}^{+}$e $\mathrm{K}^{+} ; \mathrm{Ca}^{++}$e $\mathrm{Mg}^{++} ; \mathrm{pH}$, 
fecals coliforms and streptococcus, totals coliforms. The chemical-physics analyses are representative of the existing conditions in the river at the time of the collecting, while biological analyses are the most significant datum of the environmental state. To underline clearly the course of the measured concentrations along the principal course some graphs have been created relating to the salts, the conductivity, the sulfates, the dissolved oxygen, the streptococcus and coliforms, and the nutrients.

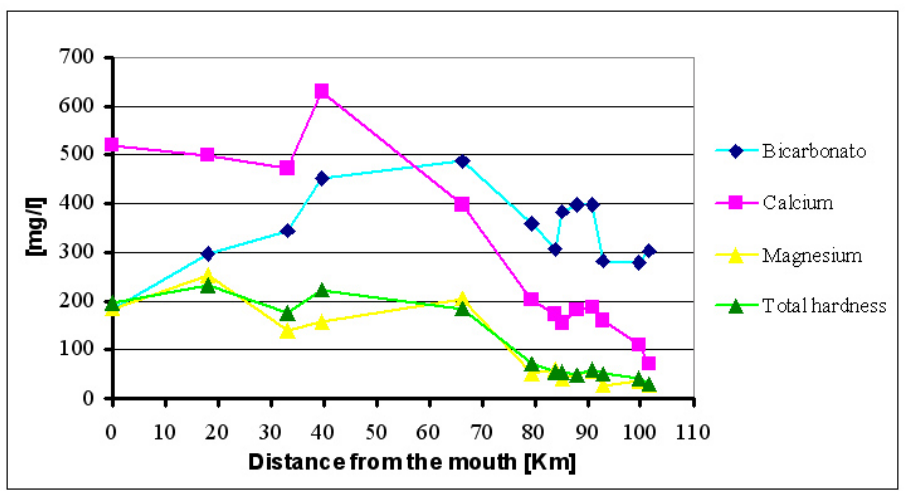

Figure 7: $\quad$ State of the $\mathrm{HCO}_{3}{ }^{-}, \mathrm{Ca}^{++}, \mathrm{Mg}^{++}$along the main course.

The ammonia values, nitrite and nitrates, fig. 8 , are indicative of the presence of wastewater and the effectiveness for the depurative treatments.

Observing the following graphs, in particular all those of salts and of conductivity, it can be deduced that the river is constituted by two separate ecosystems. The first ecosystem includes the mountain part of the watershed from Lake Fanaco up to the "Torrente Salina". The second one goes from "Vallone Salina" up to the mouth of the Platani River. The element of separation is the immission of "Vallone Salina" in the River Platani fig. 9-10.

The values of chlorides, sodium sulfates and the remarkably effects that the conductivity increase after the impluvium coming out of the mine are shown in fig. 4.

Calcium and magnesium gradually increase beginning from the same point of immission, fig. 7.

The station of testing: Ponte Vecchio, in the commune of Castronovo can be considered another critical site.

The dissolved oxygen, fig. 6 , keeps varying with values among 6 and $13 \mathrm{mg} / \mathrm{l}$. The only value that is quite far from that is the one in correspondence of the station of the "Ponte Vecchio", where the measure is $3,10 \mathrm{mg} / \mathrm{l}$. This is due to the presence of the dumpwater of the Castronovo and Lercara.

The course of the phosphates and the total phosphorus, fig. 8, shows a peak in correspondence of the Ponte Vecchio, and is almost constant in the other points.

In the same sampling station an elevated concentration of fecals streptococcus, fecal and total coliforms has been recorded, fig. 8 . 

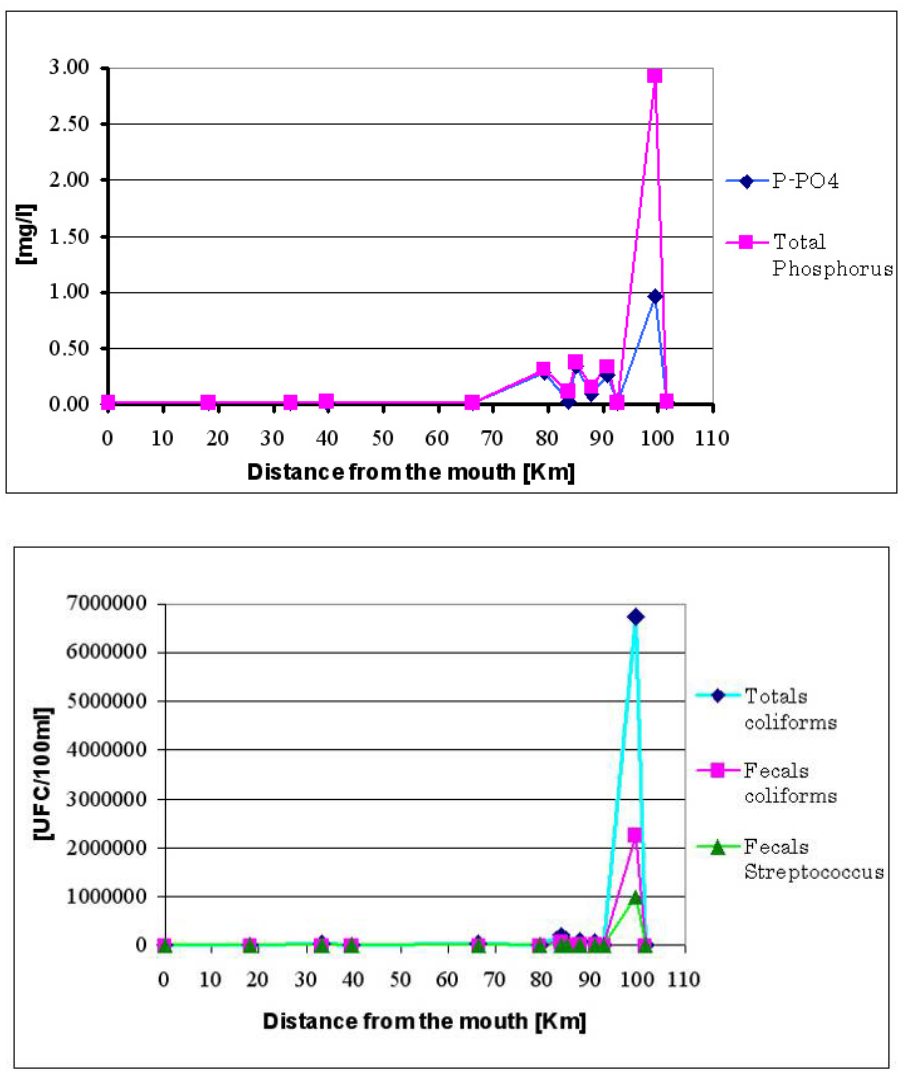

Figure 8: State of the phosphorus and compounds and coliforms, streptococcus along the main course.

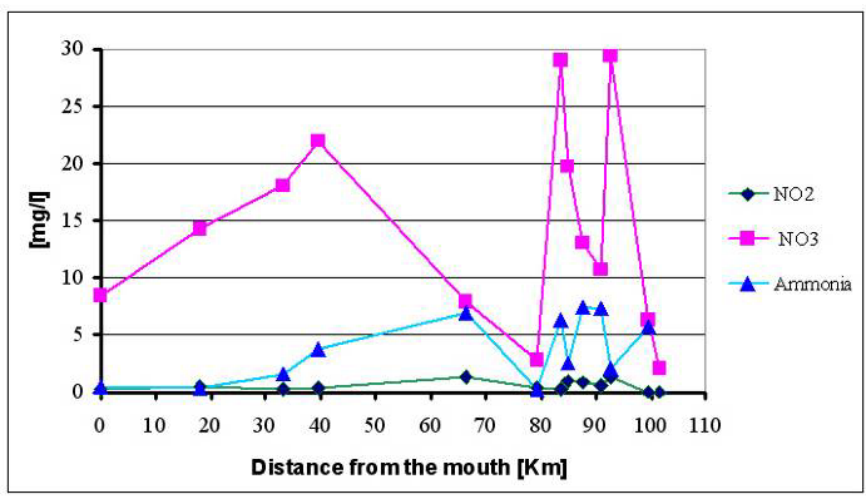

Figure 9: $\quad$ State of the nitrogen's compounds along the main course. 
158 Environmental Health Risk IV

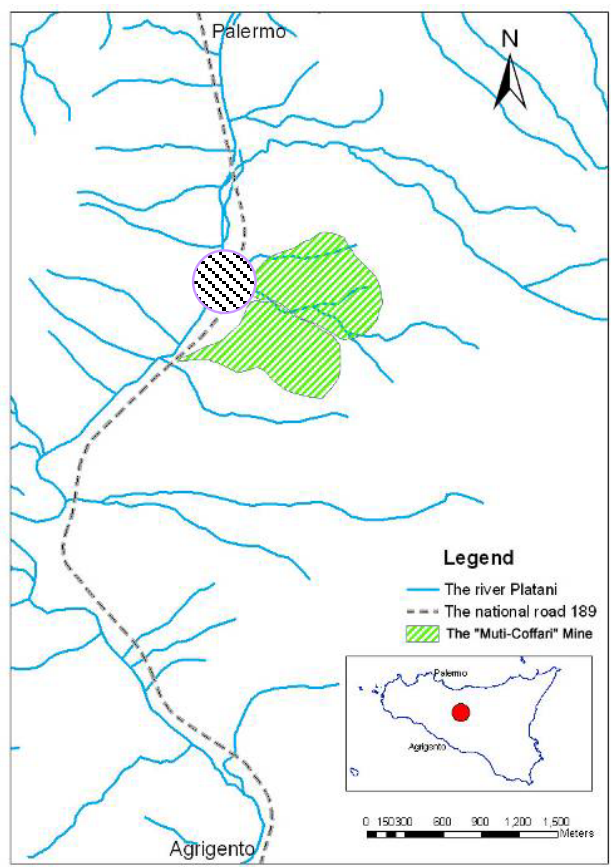

Figure 10: 8 Location of the valley of the salt water ("Muti-Coffari" mine).

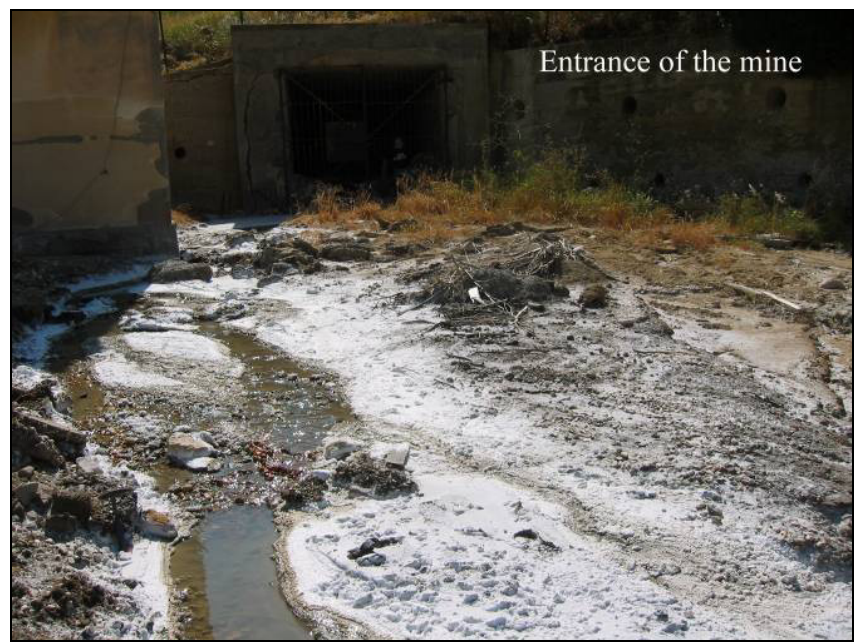

Figure 11: Entrance of the "Muti-Coffari" mine from where exit the salt water. 


\section{Conclusions}

The river is formed by two separate ecosystems. The first ecosystem is included in the mountain part of the watershed from the Lake Fanaco up to the Torrente Salina. The second goes from the Torrente Salina up to the mouth of the Platani River. The element of separation is formed and set up by the immission of the Torrente Salina that changes the conditions of waters rendering them saline and altering the fluvial ecosystem.

The presence of the mine "Muti-Coffari" effects the state of waters of the River Platani, altering the physical-chemical characteristics.

The salt that flows into the river dries the cultivations, causes the reduction of fish numbers and leads to their death, alters the ecosystem and produces desertification of the fertile areas since it is not possible to use the waters of the Platani River for the irrigation. The mine constitutes also a serious risk for the environment as it alters the morphology of the surrounding territory that is subjected to subsidence phenomena, with the creation of sinkholes and landslides.

The ex salt mine represents an elevated environmental level of danger and a remarkable risk: for the fluvial ecosystem, for the natural environment and for the nearby infrastructures, such as the Strada Statale 189 Palermo-Agrigento.

\section{References}

[1] Renda, P., Nigro F., Evoluzione geologica ed assetto strutturale della Sicilia centro-settentrionale, Boll. Soc. Geol. It. , pp. 375-388, 1999.

[2] Catalano, R., D'Argenio, B., Schema geologico della Sicilia, Mem. Soc. Geol. It. , 24, pp. 9-41, 1982.

[3] Agnesi, V. et al, Gypsum-karst caves versus surface land forms to define a morfphoevolutive model in Central Southern Sicily (Southern Italy), Sixth International Conference on Geomorphology, Zaragoza, 2005.

[4] Liguori, V., Manno, G., Mortellaro, D., Evaporite karst in Sicily, Sixth International Conference on Geomorphology, Zaragoza, 2005.

[5] Mortellaro, D., Studi preliminary per la redazione di un piano di tutela delle acque ai sensi del D. Lgs 152/99. Applicazione al bacino del fiume Platani, Tesi di laurea, Università di Palermo, 2001. 